\title{
Nestling diet optimization and condition in relation to prey attributes and breeding patch size in a patch-resident insectivorous passerine: an optimal continuum and habitat constraints
}

\author{
Grzegorz Orłowski $^{1} \cdot$ Joanna Frankiewicz $^{2} \cdot{\text { Jerzy } \mathrm{Karg}^{3}}^{3}$
}

Received: 20 February 2016/Revised: 10 June 2016/Accepted: 12 September 2016/Published online: 20 September 2016

(C) The Author(s) 2016. This article is published with open access at Springerlink.com

\begin{abstract}
Direct observational studies are needed to address dietary adjustment in species breeding in isolated non-forest habitat islands with respect to the energy demands of growing nestlings and breeding patch size. Using new dietary records determined for nestlings of Whinchat Saxicola rubetra, a dramatically declining insectivorous passerine and an indicator species of the cessation of agricultural activity, we investigated the relationships between changes in the main dietary characteristics, numerical and biomass contributions of major taxonomic and functional prey groups (expressing chitin content, vertical distribution, habitat preference and vagility within the landscape) and brood age, nestling condition and size of abandoned fields (i.e. breeding patches). Broods from larger abandoned fields received more sedentary and heavier prey like Orthoptera and soil-dwelling invertebrates, whereas the proportion of caterpillars, aerial insects and prey from vegetation decreased with increasing patch size. Nestling condition was positively correlated with the
\end{abstract}

Communicated by F. Bairlein.

Electronic supplementary material The online version of this article (doi:10.1007/s10336-016-1394-7) contains supplementary material, which is available to authorized users.

Grzegorz Orłowski

orlog@poczta.onet.pl

1 Institute for Agricultural and Forest Environment, Polish Academy of Sciences, Bukowska 19, 60-809 Poznań, Poland

2 Ornithological Society of Silesia, Zoological Institute of the University of Wrocław, Sienkiewicza 21, 50-335 Wrocław, Poland

3 Department of Nature Conservation, Faculty of Biological Sciences, University of Zielona Góra, Prof. Z. Szafrana 1, 65-516 Zielona Góra, Poland proportion of caterpillars and Orthoptera or sedentary prey taxa, but negatively with the proportion of Coleoptera or vagile prey taxa in the diet, though not with patch area. This suggests that parent Whinchats can overcome the habitat constraints resulting from the small area of an abandoned field by interchangeably incorporating the two major prey groups (Orthoptera or Lepidoptera) into the diet they feed to their nestlings. This implies a continuum in dietary optimization that is a trade-off between a brood's nutritional demands and the parents' ability to deliver topranked invertebrates present mostly within the breeding patch.

Keywords Nestling development - Dietary adjustment . Invertebrate prey $\cdot$ Optimal foraging theory $\cdot$ Single-prey loaders

\section{Zusammenfassung}

Optimierung der Nestlingsnahrung und -kondition im Verhältnis zu Beuteeigenschaften und Brutreviergröße bei einem ortstreuen insektivoren Singvogel: ein optimales Kontinuum und habitatbedingte Zwänge

Um Ernährungsanpassungen bei Arten, die in isolierten unbewaldeten Habitatinseln leben, im Hinblick auf den Energiebedarf wachsender Nestlinge und die Brutreviergröße $\mathrm{zu}$ untersuchen, sind direkte Beobachtungen erforderlich. Mithilfe neuer Ernährungsdaten, die an Nestlingen von Braunkehlchen Saxicola rubetra, einem dramatisch zurückgehenden insektenfressenden Singvogel und einer Indikatorart für die Einstellung landwirtschaftlicher Aktivitäten, erhoben wurden, untersuchten wir die Beziehungen zwischen Änderungen der primären Ernährungsparameter, zum 
Beispiel der Anteile bezüglich Anzahl und Biomasse der taxonomischen beziehungsweise funktionalen Hauptbeutegruppen (als Maß für den Chitingehalt, die vertikale Verteilung, Habitatpräferenzen und die Beweglichkeit innerhalb der Landschaft), und dem Brutalter, der Nestlingskondition sowie der Größe aufgelassener Felder (d. h. Brutreviere). Bruten von größeren, brachliegenden Feldern bekamen mehr ortsgebundene und schwerere Beuteobjekte wie Heuschrecken und bodenlebende Wirbellose, wohingegen der Anteil an Raupen, Fluginsekten und auf Vegetation gefangener Beute mit zunehmender Gebietsgröße abnahm. Die Nestlingskondition korrelierte positiv mit dem Anteil an Raupen und Heuschrecken beziehungsweise ortsgebundener Beutetaxa, jedoch negativ mit dem Anteil an Käfern oder beweglichen Beutetaxa an der Nahrung, allerdings nicht mit der Revierfläche. Dies legt nahe, dass Braunkehlcheneltern die Habitatnachteile, die aus der geringen Flächengröße eines aufgegebenen Feldes entstehen, überwinden können, indem sie wechselweise die zwei Hauptbeutegruppen (Heuschrecken oder Schmetterlinge) in die Nahrung aufnehmen, mit der sie ihre Nestlinge füttern. Dies bedeutet ein Kontinuum der Ernährungsoptimierung, die einen Kompromiss zwischen dem Nährstoffbedarf einer Brut und der Fähigkeit der Eltern, die hochwertige, überwiegend im Brutrevier vorkommende Wirbellose herbeizuschaffen, darstellt.

\section{Introduction}

Habitat fragmentation can adversely affect the reproductive success of birds primarily through reducing pairing success, lowering the survival of adults through nest predation and parasitism, and reducing the availability of critical resources such as food (Le Tortorec et al. 2013). In particular, small habitat patches may supply little food owing to their being completely isolated or of inferior quality. This may adversely affect reproductive success, since habitat patch size limits territory size and hence food availability. Even if the territory size in poor habitats could be enlarged, this would come at a cost because of the longer foraging distances required (reviewed in Le Tortorec et al. 2013). Therefore, the size of the breeding patch can influence the nutritional status of growing nestlings because adults feeding altricial young will be constrained in their foraging by the location of the nest (Hinsley et al. 1999; Zanette et al. 2000). To date, however, studies of area sensitivity in birds have basically not been oriented towards food resources or their potential changes mediated by patch size (Ribic et al. 2009; Bayard and Elphick 2010).
There are many studies looking at the effects of the quality of diet (prey species) on reproductive success (e.g. Guillod et al. 2016; reviewed in Lourenço et al. 2015). Early nutrition is often a strong predictor of offspring size, morphology and survival (cf. Wilkin et al. 2009). The quality of early diets is difficult to assess in wild populations and as such, quality is often inferred from alternative factors such as the length of the rearing period, observable parental care, natal habitat quality, offspring growth rates or condition at independence (reviewed by Wilkin et al. 2009). The food supply is a critical factor for growing nestlings (Martin 1987; Wilkin et al. 2009), the diets of which can differ from those consumed by adult/parent birds (Radford 2008; Wilson et al. 2004; Orłowski et al. 2014a). Therefore, not only the amount of food, but its quality, e.g. in terms of the availability of soft-bodied invertebrate prey such as spiders or caterpillars, may be more important for developing nestlings (Radford 2008; Ramsay and Houston 2003; Orłowski et al. 2014a, 2015). Moreover, according to a theory developed to examine how animals might be expected to behave when foraging to maximise their biological fitness (Krebs and Davies 1991), the optimal diet of nestlings and foraging strategy of parent birds are determined by the simultaneous solution of various cost-benefit functions that ultimately affect the fitness of the foragers. This primarily involves foraging costs, the handling and ingestion of food, the risk of predation, increased thermoregulatory costs, reduced time for territorial activities, and the potential consumption of toxic or inhibitory compounds (reviewed in Brodmann and Reyer 1999).

Most of the few studies analysing the relationship between breeding patch size or edge effect and diet or condition (including studies of immune function and stressinduced hormones) in adults and/or dependent young birds were conducted in woodland areas (Burke and Nol 1998; Zanette et al. 2000; Suorsa et al. 2003; Weldon and Haddad 2005; Wilkin et al. 2009). Analogous studies in non-forest, open habitat islands, like remnant or non-cropped habitats (i.e. various grassland or steppe-like sites with or without limited human activity) within an agricultural matrix are exceptions [involving adult males (Keyel et al. 2012); for review relating to North American grassland birds, see Ribic et al. (2009)]. It is still rare, however, to come across studies providing evidence that the limited availability of food is a major detrimental effect of habitat fragmentation or area sensitivity of species living in habitat fragments. The food shortage hypothesis does not appear to have been taken into account as a potential major explanation for the population decrease of ground-nesting birds breeding in isolated grassland patches [analysis of the stomach contents of adult birds (Wiens and Rotenberry 1979; reviewed by Ribic et al. 2009)]. 
In the current global context, many species of grassland birds associated both with natural open non-forest habitats such as prairie grasslands (North America) and semi-natural ones (like meadows extensively managed in Europe during recent centuries) are of conservation concern owing to their dramatic population decline caused by land use change, agricultural intensification and climate change (Murphy and Moore 2003; Sanderson et al. 2006; Møller et al. 2008; Ribic et al. 2009). Therefore, direct observational studies focusing on the question of dietary adjustment in species breeding in isolated non-forested habitat islands with respect to the energy demands of growing nestlings and the physical and landscape features of a breeding patch, such as its size, are urgently needed. Such knowledge is central to understanding the processes that drive area sensitivity in birds through potential changes of their body condition and/or survival of predator populations within highly fragmented landscapes, and their extinction when resources become insufficient (Zanette et al. 2000; Vickery and Herkert 2001; Ribic et al. 2009). It is also indispensable in the application of diet/foraging optimality theory to conservation science.

In this paper we present the results of a dietary investigation into a drastically declining insectivorous passerine bird, the Whinchat Saxicola rubetra. Since 1980 it has undergone an estimated $71 \%$ long-term decline in abundance in Europe, which has resulted in an exceptionally high level of interest in ecological/conservation investigations of this species (Henderson et al. 2014; Strebel et al. 2015; cf. Bastian and Feulner 2015). The primary breeding habitat of Whinchat used to be invertebrate-rich grasslands, especially those lying within traditionally managed agricultural landscapes, where the abundance and diversity of arthropod prey were higher than in intensively managed grasslands (Oppermann 1999; Bastian and Bastian 1996; Britschgi et al. 2006; Broyer et al. 2012; Strebel et al. 2015). The recent population decline of grassland birds, including the Whinchat, has been ascribed mainly to nest losses/female mortality resulting from more intensive agriculture practices, primarily earlier and more frequent mowing (Grüebler et al. 2008, 2012), deteriorating food/foraging conditions in semi-natural grasslands/meadows and the loss of marginal habitats (Müller et al. 2005; Britschgi et al. 2006; Perlut et al. 2008; Broyer 2009; Broyer et al. 2012, 2014; Henderson et al. 2014; Strebel et al. 2015). A very recent investigation has found evidence that mortality in Whinchats occurs primarily outside the wintering period, i.e. mostly during the migratory and breeding stages; overwintering conditions thus exert a minimal influence on the survival of this declining species (Blackburn and Cresswell 2016). As a result of the socioeconomic transformation of agriculture and resulting land abandonment in Central and Eastern Europe in the last
20-30 years, Whinchats have successfully recolonized abandoned crop fields and its populations have increased considerably in certain areas (Orłowski 2004, 2005; Tryjanowski et al. 2009; Sanderson et al. 2013; Shitikov et al. 2015).

Our earlier studies of the ecology and biology of Whinchats in this new habitat type had shown that during the breeding period the species was area-sensitive and the probability of occupancy of an abandoned field was positively correlated with field area (Orłowski 2004). Adult Whinchats search for invertebrate prey from a perch, flying to and taking prey mainly from the ground or in vegetation, sometimes in flight, then return to the perch (Andersson 1981; Bastian and Bastian 1996; Suter 1988; Pudil and Exnerová 2015). Moreover, an earlier investigation showed that in Whinchats breeding in grasslands, hunting in the air was less effective than ground foraging; prey taxa taken in the air (ca. $20 \%$ of all foraging flights), mostly during calm weather (when flying insects are more active), are less profitable compared to prey items obtained from the soil surface or vegetation on cooler days (Bastian and Bastian 1996; Suter 1988). Overall, in grassland habitats Whinchats feed their young larger and more profitable (i.e. more highly chitinized) prey as they grow older; during the brood-rearing period, adults can fly as far as $400 \mathrm{~m}$ in order to acquire the optimal food type (i.e. caterpillars) (Bastian and Bastian 1996). Furthermore, the mowing of grasslands (compared to abandoned farmland) is detrimental to the invertebrate community at such sites, particularly to the larger and less vagile species like Orthoptera or Lepidoptera (Siemann et al. 1999; Humbert et al. 2009). Therefore, the diet of Whinchats may differ substantially between grasslands and abandoned farmland. Hitherto, all dietary studies of nestling Whinchats were restricted to different grassland types (reviews in Bastian and Bastian 1996; Suter 1988; Britschgi et al. 2006), with hardly any detailed dietary data for Whinchats (and other bird species) breeding in abandoned farmland. Importantly, however, owing to the progressive increase in the acreage of abandoned farmland in some temperate areas of the northern hemisphere (Kamp et al. 2015), such knowledge is essential in order to diagnose the biodiversity and viability of bird populations in this habitat (Kamp et al. 2015; Tryjanowski et al. 2009; Sanderson et al. 2013; Plieninger et al. 2014; Zakkak et al. 2015).

Based on the above framework and considering the conditions of the natural experiment of habitat fragmentation of Whinchats nesting in isolated patches of noncropped vegetation in abandoned fields, we make a number of predictions linking certain features of the diet of nestlings with their physiological state, food demands and the environment. In this study we explore the following major objectives: 
1. The differences in dietary composition between nestlings in various age classes.

2. The effect on nestling diet of the area of abandoned crop fields where Whinchats bred.

3. The influence of diet on the body condition of Whinchat nestlings.

In particular, we investigate the relationships between changes in the main dietary characteristics, i.e. the numerical and biomass contribution of major taxonomic and functional prey groups (expressed by their chitin content, vertical distribution, habitat preference and vagility within the landscape) and brood age, nestling condition and breeding patch size. The functional prey group approach (i.e. the classification of invertebrates based on their individual features) was used by earlier researchers (Wiens and Rotenberry 1979; Crossley et al. 1989), as well as by ourselves in our investigations of bird diets (Orłowski et al. 2014b). We hypothesized that the contribution of some prey groups (mostly more highly chitinized prey) would increase as the nestlings grew older, but that to some degree these changes would also co-vary with patch area. Thus, some invertebrate taxa, such as large-bodied, sedentary species (or less vagile ones potentially severely negatively affected by agricultural practices/mowing like non-flying/soil-dwelling Orthoptera or Arachnidae), might be over-represented in the diet of nestlings from large patches of non-cropped vegetation, whereas mobile species, highly vagile within a landscape (Siemann et al. 1999; Tscharntke et al. 2005; Humbert et al. 2009) or living in a crop habitat, might be over-represented in smaller patches.

\section{Materials and methods}

The results are part of an extensive study of the breeding biology and ecology of Whinchats conducted in a ca. 500-ha area of agricultural landscape in south-west Poland (Frankiewicz 2008, 2010, 2015). The dominant form of land use in the region was arable, with crop fields covering about $87-93 \%$ of the total area studied. The study area was managed extensively, with small-scale farming predominant. Within the study area Whinchats breed in narrow, elongated abandoned fields, dissected by numerous field margins, fallow fields and plantations of young trees, usually not exceeding $30 \mathrm{~m}$ in width. In 2003-2007, a total of 246 occupied territories (including those of territorial single males which occupied their territories for more than 2 weeks) and 117 nests of Whinchats were found in the study area on 44 different abandoned fields, the optimal habitat for the species (Frankiewicz 2008, 2010). Three types of plant associations (based on Matuszkiewicz 2005) could be discerned on the abandoned fields where the
Whinchats bred: Artemisia-Tanacetum vulgaris (54\% of all abandoned fields), Convolvulus arvensis-Agropyron repens $(23 \%)$ and Koeleria glauca-Corynephorus canescens $(1 \%)$. The meadows belonged to the Arrhenatheretalia order (Malawian-Arrhenatheretea class) (Frankiewicz 2010).

During the brood-rearing period the parent Whinchats collected food primarily from abandoned fields, to which $68-89 \%$ of all the parent birds' foraging trips were made (determined for 260 flights of both adult birds from ten different nests). In our study population the average distance of a flight from the nest by parent Whinchats was $33 \mathrm{~m}$ [ \pm SD $21.2 \mathrm{~m}$, range 4-80 m (Frankiewicz 2008)]. This value was smaller compared with previous data for Whinchats foraging in extensive grasslands in Sweden [43.8 $\mathrm{m}$ (Andersson 1981)] or Alpine meadows in Switzerland [42.2-54.7 m (Britschgi et al. 2006)]. Moreover, pairs of Whinchats breeding in narrow, long-abandoned fields often foraged in adjacent crop fields (mostly oil-seed rape, but avoiding winter cereals) compared to pairs breeding in large patches of non-cropped vegetation (Frankiewicz 2010).

\section{Determination of nestling diet and body condition}

Our description of the Whinchat nestling diet is based on faecal analysis, the material for which was sampled from 47 nests examined in 2004-2007. In these 4 years, 177 faecal sacs were sampled: 63 (in 2004), 66 (2005), 20 (2006) and 28 (2007). The faecal sac sampling dates were as follows: 24 May-16 June 2004, 30 May-30 June 2005, 5-14 June 2006, 26 May-16 June 2007. We sampled between one and 13 faecal sacs (on average four) from each nest, which were then used in our analysis.

The nests from which we sampled faecal sacs were distributed in 22 abandoned fields, ranging in area from 0.1 to 6.8 ha (average $=1.52 \mathrm{ha}$ ). Six of these fields were $<0.5$ ha, four were $0.5-1$ ha, seven were $1-2$ ha, and four $2-4$ ha; one field was $>5$ ha. In order to graphically present and prevent pseudoreplication of dietary data derived from the same broods, we allocated the dietary data to fields of four size classes: $<0.75$ ha (39 faecal sacs), $0.75-1.5$ ha (36), 1.5-3 ha (57) and $>3$ ha (45).

The nests were inspected several times during the season in order to establish the onset of egg-laying and clutch size (Frankiewicz 2010). Throughout the expected hatching period nests were monitored daily to determine the exact hatching date. In the case of nests discovered only after egg-laying or hatching, the hatching date was back-calculated based on the stage of the nestlings' development. Over the years of the entire study (2003-2007), nestlings from 96 broods were weighed and the length of the second primaries measured (Frankiewicz 2010). The nestlings 
from which the faecal sacs were sampled were aged according to parallel measurements of body weight and feather development of other individually marked nestlings in nests located in the same area. Their ages ranged between 3 and 11 days old; the sample size of particular nestling age classes is shown in Fig. 1. Since some faecal sacs were collected from the same broods on consecutive days, the dietary data for these broods were treated separately in various age categories in the subsequent analysis. The age of the nestlings from which we sampled faecal sacs varied among the four study years (Kruskal-Wallis test, $\left.H_{3,177}=24.3, P<0.001\right)$.

We estimated the index of nestling body condition (hereafter for simplicity referred to as "nestling body condition') based on the residuals from a regression of body mass on the length of the second primary (Bortolotti et al. 2000; Frankiewicz 2010). The index of body condition was calculated on the basis of average values for the entire brood, which most often comprised nestlings in one age class, i.e. nestlings hatched within $24 \mathrm{~h}$ in $94 \%$ of the 37 nests investigated (Frankiewicz 2010). In order to analyse in detail the relationship between nestling condition and diet, we used data for a smaller set of broods of known body condition: 32 different broods aged between 4 and 10 days investigated in 2004-2007 ( $n=135$ faecal sacs). The number of faecal sacs sampled were as follows: 13 from 4-day-old broods, 30 from 5-day-old broods, 30 from 6-day-old broods, 41 from 7-day-old broods, 4 from 8-dayold broods, 5 from 9-day-old broods and 12 from 10-day- old broods. For the graphical presentation of dietary data for nestlings with different body condition, and to prevent pseudoreplication, we arbitrarily divided these nestlings into three groups according to the residuals obtained from the regression analysis (see above). Hence, we classified the condition of nestlings with the lowest residuals as 'poor', i.e. $<0$ (samples from 19 broods; 74 faecal sacs); those with residuals between 0 and 1 as 'medium' (nine broods; 38 faecal sacs); and those with residuals $>1$ as 'good' (five broods; 23 faecal sacs).

Before analysis the faecal sacs were crushed manually and separated on Petri dishes. The food components in the faecal sacs were identified under a binocular microscope at $40 \times$ magnification. The number of prey items representing particular invertebrate taxa present in each individual faecal sac was established from the numbers of fragments of chitin parts, chiefly the elytra (for different families and genera of Coleoptera, Homoptera or Heteroptera), wings (in the case of Diptera, Hymenoptera), mouthparts (most of the orders) and other preserved organs (e.g. limbs, perilous, clypeus, mandible). During the determination of the number of prey items belonging to a particular taxon, a rule summing the different chitin parts to the level of one individual was applied: two or more different fragments of chitin parts (e.g. head, mandibles, six legs and other parts in the case of ants) from one faecal sac were treated as belonging to the same individual of a given species (Orłowski and Karg 2011, 2013). The mass of prey was calculated as dry mass (milligrams dry weight); these
Fig. 1 The four main dietary characteristics (average \pm SE) determined for individual faecal sacs $(n=177$ in total) of nestling Whinchats Saxicola rubetra vs. nestling age sampled in abandoned crop fields in south-west Poland, 2004-2007. Number of prey taxa $=$ diet diversity. The sample sizes for consecutive age classes of nestlings are: 3 days $(d)$ old ( $n=6$ faecal sacs), 4 days old $(n=10), 5$ days old $(n=35)$, 6 days old $(n=30), 7$ days old $(n=43), 8$ days old $(n=13)$, 9 days old $(n=18), 10$ days old $(n=16)$ and 11 days old $(n=6)$
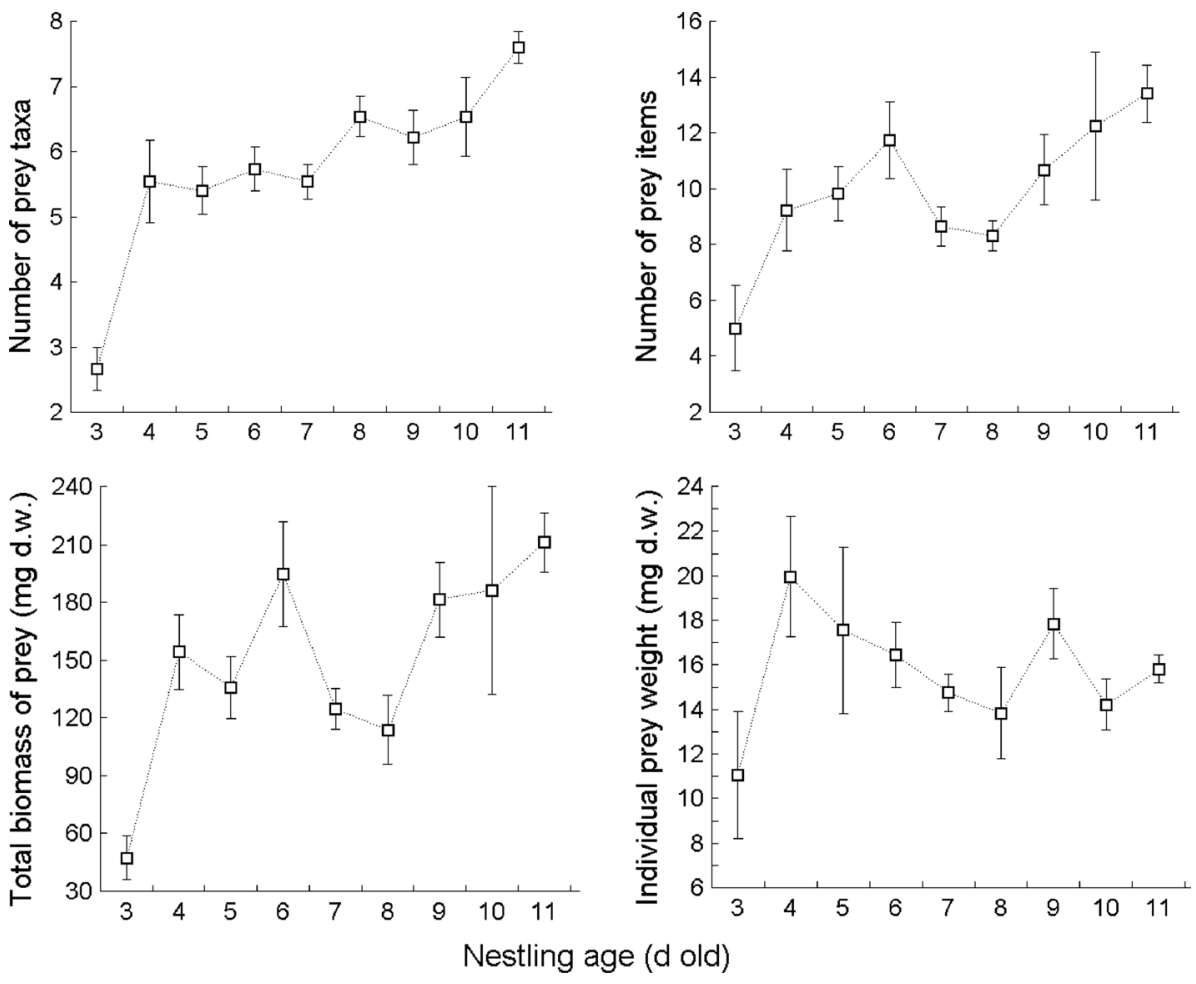
values were obtained from detailed measurements of insect weights based on the analysis of 479,087 individuals of different insect taxa (Karg 1989).

\section{Data analysis}

Initially, we identified invertebrate prey items to the lowest possible taxonomic level. However, we assumed that the taxonomic composition of the prey alone would be insufficient to fully explain the relationship between breeding patch habitat/size in non-cropped vegetation and/or changes in the composition of prey. Thus, in order to provide an adequate description of these changes and a meaningful biological interpretation, including the food requirements of growing nestlings, we arbitrarily grouped the identified prey species/taxa into the following different classes based on their individual features and functionality within the landscape/habitat (hereafter referred to as 'functional prey groups'):

1. Chitin content (less, intermediately and highly chitinized prey).

2. Vertical distribution (soil-dwelling invertebrates, soil/ vegetation up to ca. $1 \mathrm{~m}$ and aerial invertebrates).

3. Habitat preference (eurytopic taxa, associated with crops or non-cropped habitats).

4. Vagility of species/taxa within the landscape (sedentary or vagile taxa).

These classifications were based on our previous ecological studies of various groups of invertebrate taxa in an agricultural landscape, including the classification of invertebrates into functional prey groups and the use of such an approach in dietary studies of insectivorous birds (Orłowski et al. 2014b). A detailed classification of all the identified prey taxa is presented in Table S1.

For each faecal sac we determined the four main dietary characteristics (diet diversity expressed as the number of prey taxa, total number of prey, total biomass of prey and individual prey weight) and the composition of the diet expressed as the number, percent number (\%number), biomass and percent biomass (\%biomass) representing the seven major taxonomic prey groups [classes/orders of invertebrates: Heteroptera, Coleoptera, Hymenoptera/Diptera, Lepidoptera (larvae), Orthoptera, Aranaea; other invertebrates comprising Mollusca, Diplopoda and unidentified insects] and prey groups with four different classifications of the functionality of invertebrate taxa (i.e. chitin content, vertical distribution, habitat preference and vagility within the landscape).

Three major objectives were explored in the statistical analyses. First, we assessed the age-related differences in the main dietary characteristics (ANOVA), the contribution of the seven major food types and the different functional prey groups [multivariate ANOVA (MANOVA)] between nestlings in nine age classes ( $>3-11$ days old) using Statistica 7.0 (Statsoft 2007). To resolve the problem of pseudoreplication, these analyses were performed using ANOVA/MANOVA with a nested design and a mixedmodel approach with brood identity as a random term; the independent variables were nestling age and individual brood identity (nested within nestling age).

Second, we assessed the effect of the area of the abandoned crop fields (expressed in hectares) where Whinchats bred on the four main dietary characteristics and composition of nestlings. Third, we tested the influence of the main dietary characteristics and composition, i.e. the contribution of the seven major food types and different functional prey groups, on the body condition (the residuals from a regression of body mass on the length of the second primary) of Whinchat broods. Both of these analyses were performed separately for each of the dietary characteristics and individual taxonomic and functional prey groups (in terms of their \%biomass) using the generalized linear model module (GLZ) with mixed design in Statistica 7.0 (Statsoft 2007) with normal distribution and logarithmic link function. To control for the non-independence in the generalized linear mixed models (GLMMs), the individual brood identity was nested within the age of nestlings. The model statistics were the estimate $( \pm \mathrm{SE})$ and Wald $\chi^{2}$ value. We believe that our approach treating each individual prey group separately in these two analyses is justified because in $90 \%$ of cases parent Whinchats brought individual invertebrate prey items to the nestlings (Frankiewicz 2010).

To meet the assumption of normality some data were $\log$ transformed; in addition, all percentage data were square root-arcsine transformed prior to analysis. The statistical analyses were done using Statistica 7.0 (Statsoft 2007) and Excel software. The probability of $P<0.05$ was considered statistically significant.

\section{Results}

The analysis yielded 1778 individual invertebrate prey items representing 58 various taxa in all the faecal sacs examined. The most numerous prey items were Coleoptera (47.6\%), followed by Arachnidae (for simplicity, hereafter, Araneae; $13.4 \%$ ), Heteroptera (10.2\%), Hymenoptera $(10.2 \%)$, Orthoptera (6.5\%), Diptera (5.9\%), Lepidoptera larvae $(2.8 \%)$, Diplopoda $(2.3 \%)$ and other prey (Mollusca, Nematoda and unidentified insects; $1.1 \%$ ) (Table S1). 


\section{Effect of nestling age on diet composition}

Three of the four main dietary characteristics analysed (Fig. 1), i.e. dietary diversity, the number of prey items and the biomass of prey exhibited significant variations in relation to both partial effects tested, i.e. Brood identity (Age) and Age, and showed a highly significant and close fit in the overall model and apparent increase with age (Table 1). In contrast, the average mass of prey (Fig. 1) was significantly related only to the Brood identity (Age) (Table 1). Furthermore, although the fit in the overall model for the average mass of prey was also statistically significant (Table 1), the trend of the changes, especially in nestlings older than 4 days suggests a decrease in the average mass of prey (Fig. 1).

The results of the MANOVA showed that the dietary composition, expressed as the number, \%number, biomass and \%biomass of the seven major taxonomic prey groups/food types (class/orders of invertebrates) (Fig. 2; Fig. S1) and four functional prey groups in terms of chitin content, vertical distribution, habitat preference and vagility of a species/taxa within the landscape (Fig. 3; Fig. S2), varied markedly both with the age of nestlings and between various broods, as indicated by the output of the partial effect of brood identity nested within age (Table 2). In consecutive age classes of nestlings we observed a large variation in the contribution of each of the seven major taxonomic prey/food types. In particular, the \%biomass of prey between the 3rd and 4th day displayed the most pronounced differences in variation: Orthoptera (up to ca. eightfold increase), Aranaea (ca. sevenfold decrease), Coleoptera (ca. twofold decrease) (Fig. 2).

Lastly, the post hoc contrast (Tukey's test) from the MANOVA showed that the numerical contribution of three of the seven major taxonomic prey groups/food types (Aranaea, Lepidoptera larvae and Orthoptera) to the diet varied significantly among the four study years.
Nestlings received more highly chitinized prey as they grew older. This was especially evident in the \%biomass of highly chitinized prey, which increased significantly with nestling age (Spearman rank correlation coefficient, $r_{\mathrm{s}}=0.717, P=0.030$; Fig. 3). Interestingly, the contribution pattern of \%number and \%biomass of the three other functional prey groups, expressing their vertical distribution, habitat preference and vagility within the landscape, showed no clear age-related trend (Fig. 3). So nestlings were fed predominantly prey items from vegetation ( $>70 \%$ of prey biomass), and eurytopic prey items constituted $>50 \%$ of the prey biomass in each age class, whereas typical soil-dwelling invertebrates made up no more than $10 \%$ of the biomass consumed (Fig. 3; Fig. S2). Lastly, over the entire brood-rearing period the number and $\%$ number of prey representing sedentary taxa were consistently higher compared to vagile taxa; however, the biomass and \%biomass of both these prey groups showed large day-to-day variations (Fig. 3; Fig. S2).

\section{Relationship between diet and nestling condition, and breeding patch size}

The results of the GLMMs showed the statistically significant effect of the area of the abandoned field where the Whinchats bred on 17 of the 23 dietary characteristics/contributions of \%biomass of major prey groups analysed, including nine positive and eight negative influences (Table S2). In particular, we found evidence that broods from larger abandoned fields received heavier prey items and consumed more Araneae, Diplopoda/Mollusca, Orthoptera, Hymenoptera, sedentary taxa, soil-dwelling invertebrates, eurytopic taxa or highly chitinized prey. On the other hand, the contribution of Coleoptera, Heteroptera, Lepidoptera larvae, intermediately chitinized, crop-specific, non-crop specific, vagile prey or prey from vegetation, as well as aerial insects, decreased in their diet (Fig. 4; Table S2).

Table 1 Results of ANOVA (type III SS) testing the effect ( $F$-values) of age (days) and brood identity (nested within age) on the main dietary characteristics identified for faecal sacs of Whinchat Saxicola rubetra nestlings (see Fig. 1)

\begin{tabular}{|c|c|c|c|c|}
\hline \multirow[t]{2}{*}{ Source of variation } & \multicolumn{2}{|l|}{ Effect } & \multicolumn{2}{|l|}{ Model } \\
\hline & Brood identity $(\mathrm{Age})^{\mathrm{a}}$ & $\mathrm{Age}^{\mathrm{b}}$ & $R^{2}$ & $P$ \\
\hline Diet diversity ( $n$ taxa) & $2.37 * * *$ & $2.65^{*}$ & 0.473 & $<0.0001$ \\
\hline Number of prey items & $3.59 * * *$ & $5.02 * * *$ & 0.543 & $<0.0001$ \\
\hline Biomass of prey & $4.65 * * *$ & $6.73 * * *$ & 0.612 & $<0.0001$ \\
\hline Average mass of prey & $1.50^{*}$ & 1.65 (n.s.) & 0.345 & 0.045 \\
\hline
\end{tabular}

$* P<0.05, * * * P<0.001$ (statistical significance for partial effects)

a $d f=38$

b $d f=8$ 

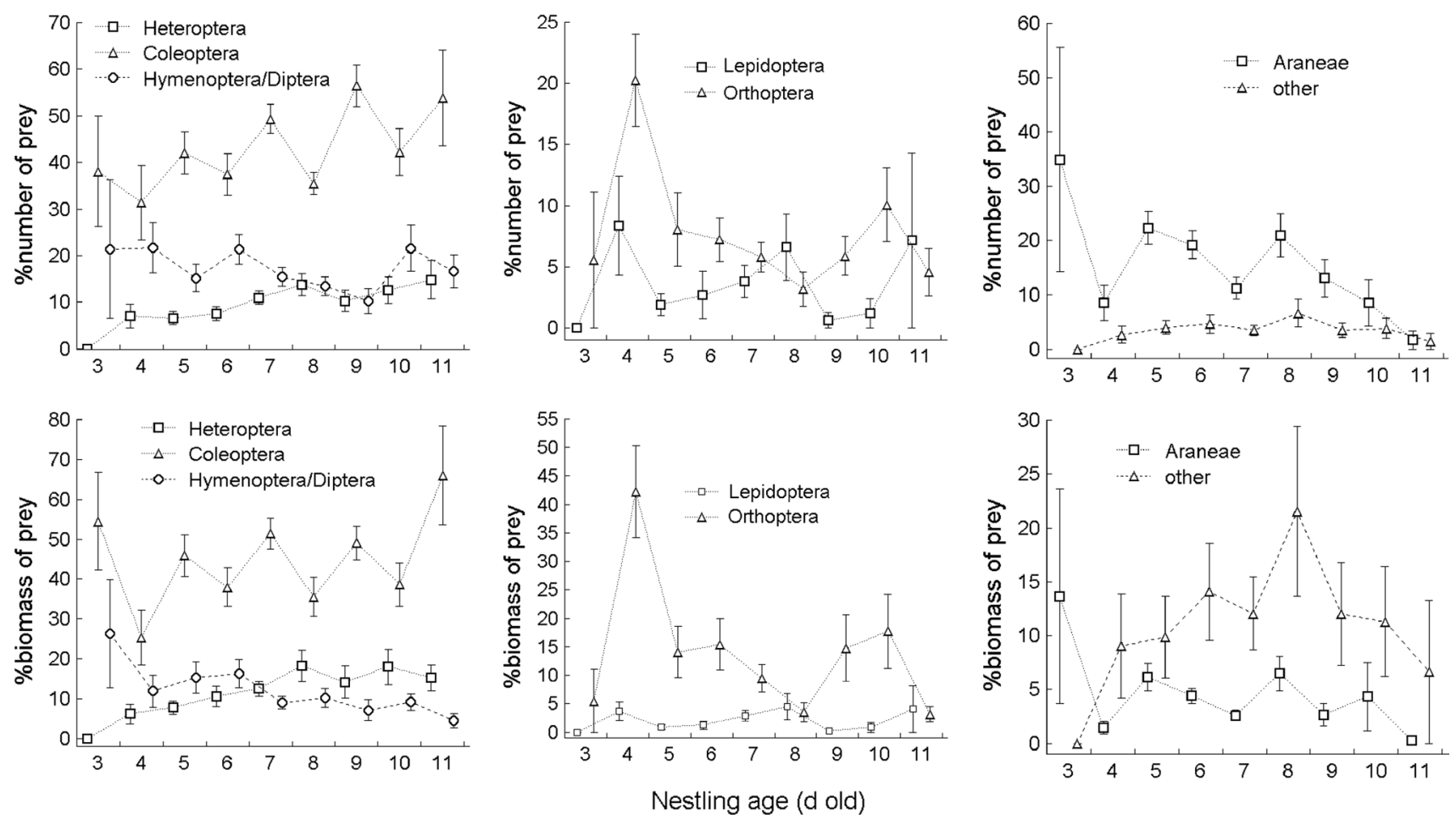

Fig. 2 The average $( \pm \mathrm{SE})$ percent number (\%number) and percent biomass (\%biomass) of seven major prey/food types (class/orders of invertebrates) identified in faecal sacs of nestling Whinchats $S$.

Nestling condition was significantly correlated with six of the 23 dietary characteristics/contributions of \%biomass of major prey groups analysed, including four positive and two negative relationships (Table S3; Fig. 5). Evidence was forthcoming that the \%biomass of Lepidoptera larvae, Orthoptera, less chitinized or sedentary prey were positively correlated with nestling condition, while the \%biomass of Coleoptera and vagile prey were negatively correlated with nestling condition (Fig. 5; Table S3). Finally, nestling condition was not correlated with the area of the abandoned field where Whinchats bred (GLMM, with nest identity as a random term, estimate $=-0.022$, $\left.\mathrm{SE}=0.026, \chi^{2}=0.74, P=0.390\right)$.

\section{Discussion}

Our study demonstrated several major results documenting the effect of open non-forest habitat fragmentation or patch size effect on individual fitness and dietary optimization in passerine nestlings, as well as complementing basic dietary information on a declining insectivorous grassland passerine in a novel breeding habitat.

First, we found that nestling Whinchats received more chitinized prey as they grew older, which overall is in line of the idea of the selective foraging of parent birds to meet rubetra vs. nestling age. Other prey are Diplopoda, Mollusca, Nematoda and unidentified insects; for the number and biomass of prey, see Fig. S1

the specific nutritional needs of offspring in different age classes (Flinks and Pfeifer 1988; Magrath et al. 2004; Radford 2008; Mitrus et al. 2010; García-Navas et al. 2012), and agrees with earlier dietary studies on Whinchats breeding in grasslands (reviewed by Bastian and Bastian 1996; Suter 1988). The three main dietary characteristics, i.e. diversity of diet, number of prey items and biomass of prey - the last mentioned being primarily a consequence of provisioning with heavy orthopterans-apparently increased with nestling age, which generally seems to be a function of the progressive gain in body mass, and the concurrent growing volume/quality of food ingested/digested and increasing volume of faecal sacs produced by growing nestlings (Flinks and Pfeifer 1988). In this respect, the most relevant variable describing a priori dietary changes in nestlings of increasing age and size is the average mass of individual prey items, which is only related to brood identity and is least biased (if at all) as a result of the progressive gain in body mass by nestlings. Moreover, there may exist some differences in the frequency of defecation between younger and older nestlings, which is a consequence of their receiving different amounts or quality of food (Quan et al. 2015), as well as of thermoregulation and perhaps also water regulation. Thermoregulation only comes into play in nestling Whinchats when they are 4-5 days old (Bastian and Bastian 
Fig. 3 The average $( \pm$ SE) $\%$ number and \%biomass of four functional prey groups expressing (from the top) the chitin content, vertical distribution, habitat preference and vagility of species/taxa within the landscape identified in faecal sacs of nestling Whinchats $S$. rubetra vs. nestling age. The identified prey items are listed in Table S1. For the number and biomass of functional prey groups, see Fig. S2
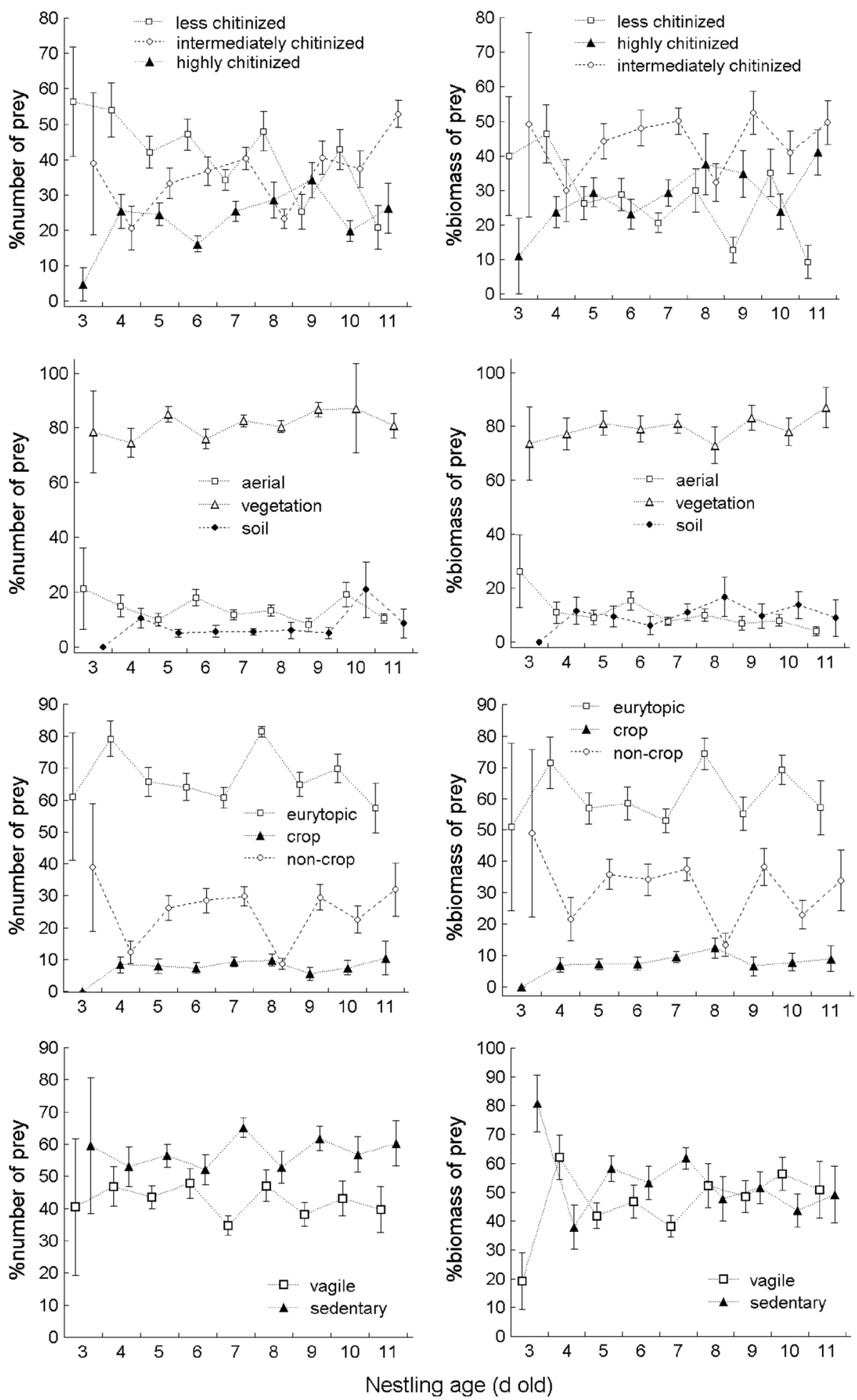

1993, 1996). In addition, the defecation efficiency in nestlings of different ages is presumably different, which may influence the passage of some prey remains to the faecal sacs.

On the other hand, an apparent inconsistency was the decrease in average mass of invertebrate prey, observed from the 4th day of life of the nestlings. As expected, the average mass of invertebrate prey should, as in three previous cases, increase progressively with nestling age, but we observed such an increase only between 3- and 4-day-old nestlings. It seems that this contradictory result may illustrate the overall ability of some insectivorous passerine nestlings to ingest large prey at an early stage of their post-natal development, which in practice can mean 
Table 2 Results of multivariate ANOVA testing the effect of age (days) and brood identity (nested within age) on dietary composition expressed as the number, percent number, biomass and percent biomass of seven major prey/food types (class/orders of invertebrates $=$ Araneae, Heteroptera, Diptera/Hymenoptera, Coleoptera, Lepidoptera larvae, Orthoptera and other invertebrates; see Fig. 2) and four functional prey groups expressing chitin content (less, intermediately and highly chitinized), vertical distribution (soil surface, soil/vegetation, aerial insects), habitat preference (eurytopic, crops and non-cropped) and vagility of a species/taxa within the landscape (sedentary and vagile species) (see Fig. 3) based on analysis of faecal sacs of nestling Whinchats S. rubetra

\begin{tabular}{|c|c|c|c|c|c|c|c|c|c|c|}
\hline \multirow[t]{3}{*}{ Source of variation } & \multicolumn{5}{|c|}{ Brood identity(Age) } & \multicolumn{5}{|l|}{ Age } \\
\hline & \multirow[t]{2}{*}{ Wilk's $\lambda$} & \multicolumn{2}{|l|}{$d f$} & \multirow[t]{2}{*}{$F$} & \multirow[t]{2}{*}{$P$} & \multirow[t]{2}{*}{ Wilk's $\lambda$} & \multicolumn{2}{|l|}{$d f$} & \multirow[t]{2}{*}{$F$} & \multirow[t]{2}{*}{$P$} \\
\hline & & $H_{\mathrm{o}}$ & Error & & & & $H_{\mathrm{o}}$ & Error & & \\
\hline \multicolumn{11}{|l|}{ Major prey/food types } \\
\hline Number of prey items & 0.013 & 266 & 867.9 & 2.86 & $<0.0001$ & 0.141 & 56 & 673.1 & 5.28 & $<0.0001$ \\
\hline Percentage of prey & 0.027 & 266 & 867.9 & 2.53 & $<0.0001$ & 0.389 & 56 & 673.1 & 2.30 & $<0.0001$ \\
\hline Biomass of prey & 0.010 & 266 & 867.9 & 3.31 & $<0.0001$ & 0.389 & 56 & 673.1 & 6.20 & $<0.0001$ \\
\hline Percentage of prey biomass & 0.017 & 266 & 867.9 & 2.64 & $<0.0001$ & 0.355 & 56 & 673.1 & 2.55 & $<0.0001$ \\
\hline \multicolumn{11}{|l|}{ Chitin content } \\
\hline Number of prey items & 0.139 & 114 & 384.3 & 3.14 & $<0.0001$ & 0.466 & 24 & 371.8 & 4.66 & $<0.0001$ \\
\hline Percentage of prey & 0.223 & 114 & 384.3 & 2.19 & $<0.0001$ & 0.674 & 24 & 371.8 & 2.56 & 0.001 \\
\hline Biomass of prey & 0.187 & 114 & 384.3 & 2.53 & $<0.0001$ & 0.473 & 24 & 371.8 & 4.55 & $<0.0001$ \\
\hline Percentage of prey biomass & 0.215 & 114 & 384.3 & 2.26 & $<0.0001$ & 0.753 & 24 & 371.8 & 1.59 & 0.039 \\
\hline \multicolumn{11}{|l|}{ Vertical distribution } \\
\hline Number of prey items & 0.145 & 114 & 384.3 & 3.04 & $<0.0001$ & 0.633 & 24 & 371.8 & 2.64 & $<0.0001$ \\
\hline Percentage of prey & 0.304 & 114 & 384.3 & 1.64 & 0.0003 & 0.840 & 24 & 371.8 & 0.96 & 0.513 \\
\hline Biomass of prey & 0.136 & 114 & 384.3 & 3.19 & $<0.0001$ & 0.598 & 24 & 371.8 & 3.01 & $<0.0001$ \\
\hline Percentage of prey biomass & 0.171 & 114 & 384.3 & 2.71 & $<0.0001$ & 0.746 & 24 & 371.8 & 1.64 & 0.030 \\
\hline \multicolumn{11}{|l|}{ Habitat preference } \\
\hline Number of prey items & 0.187 & 114 & 384.3 & 2.52 & $<0.0001$ & 0.633 & 24 & 371.8 & 1.64 & $<0.0001$ \\
\hline Percentage of prey & 0.266 & 114 & 384.3 & 1.88 & $<0.0001$ & 0.714 & 24 & 371.8 & 1.91 & 0.007 \\
\hline Biomass of prey & 0.260 & 114 & 384.3 & 1.91 & $<0.0001$ & 0.623 & 24 & 371.8 & 2.71 & $<0.0001$ \\
\hline Percentage of prey biomass & 0.261 & 114 & 384.3 & 1.91 & $<0.0001$ & 0.754 & 24 & 371.8 & 1.58 & 0.043 \\
\hline \multicolumn{11}{|l|}{ Vagility of a species/taxon } \\
\hline Number of prey items & 0.247 & 76 & 258 & 3.44 & $<0.0001$ & 0.675 & 16 & 258 & 3.50 & $<0.0001$ \\
\hline Percentage of prey & 0.341 & 76 & 258 & 2.42 & $<0.0001$ & 0.844 & 16 & 258 & 1.43 & 0.129 \\
\hline Biomass of prey & 0.334 & 76 & 258 & 2.47 & $<0.0001$ & 0.737 & 16 & 258 & 2.65 & 0.0007 \\
\hline Percentage of prey biomass & 0.376 & 76 & 258 & 2.14 & $<0.0001$ & 0.835 & 16 & 258 & 1.52 & 0.092 \\
\hline
\end{tabular}

The identified prey items are listed in Table S1

that 4-day-old nestling Whinchats can already exceed the threshold of the gape-size constraint hypothesis. Basically, the gape-size constraint hypothesis states that only nestlings of small passerines older than 7 days are not limited by gape size (cf. García-Navas et al. 2012). In the case of the Whinchat, a species relying primarily on single invertebrate prey items caught during discrete hunting events (Andersson 1981; Bastian and Bastian 1996; Frankiewicz 2010; Pudil and Exnerová 2015), the early ability of nestlings to ingest prey of large size might therefore be behaviourally justified. On the other hand, the lowest prey weight measured in 3-day-old nestlings suggests that this is the intentional work of parent Whinchats. An alternative explanation for the observed sudden increase in the average mass of invertebrate prey, prey abundance and biomass between 3- and 4-day-old nestlings is that this may have been due in part to the small sample size of the youngest (3 days old) nestlings compared with older (5-7 days old) nestlings. Indeed, the contribution of orthopteran prey did increase between days 3 and 4, but then decreased between days 4 and 5; the same applied to the decrease in Coleoptera. Moreover, the contribution of Orthoptera and two other prey groups (Aranaea and Lepidoptera larvae) varied significantly between the 4 study years, which most likely resulted in part from the unequal age distribution among the nestlings in the 4 study years, although some differences in the availability of these invertebrates at the parent Whinchats' 

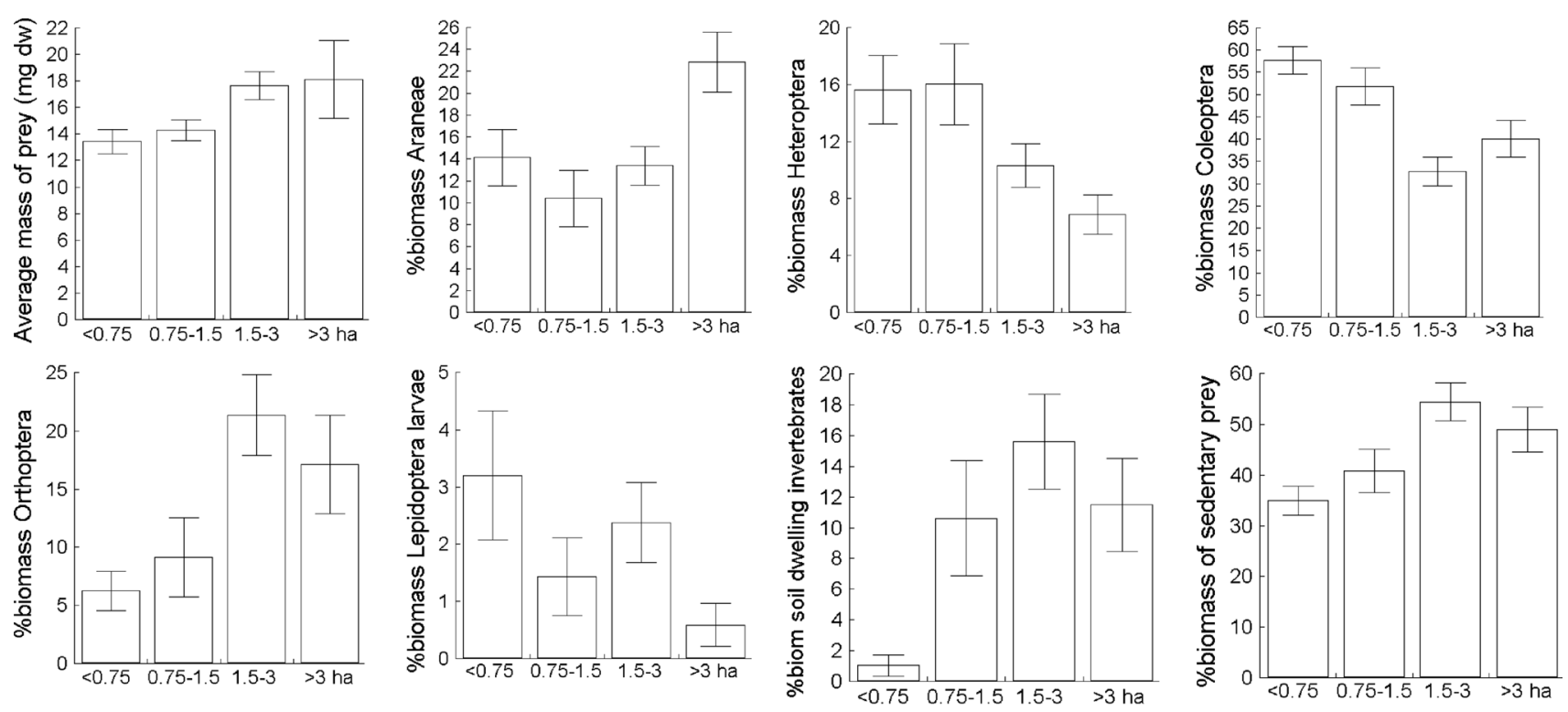

Abandoned field area (ha)

Fig. 4 Statistically significant dietary changes (average \pm SE) in nestling Whinchats $S$. rubetra averaged across broods of different ages in relation to the area of abandoned crop fields. Summary of statistical analysis (generalized linear mixed models; GLMMs) testing the effect of abandoned crop field area on these and the other dietary variables listed in Table S2
Fig. 5 Statistically significant dietary changes (average \pm SE) in nestling Whinchats $S$. rubetra in relation to their body condition based on the residuals from a regression of body mass on the length of the second primary. The condition of nestlings with the lowest residuals, i.e. $<0$, was classified as 'poor' (19 broods/74 faecal sacs), for those with residuals between 0 and 1 as 'medium' (9/38), and for those with residuals $>1$ as 'good' $(5 / 23)$.

The statistical analysis (GLMMs) testing the effect of these and the other dietary variables on the nestling body condition is summarized in Table S3
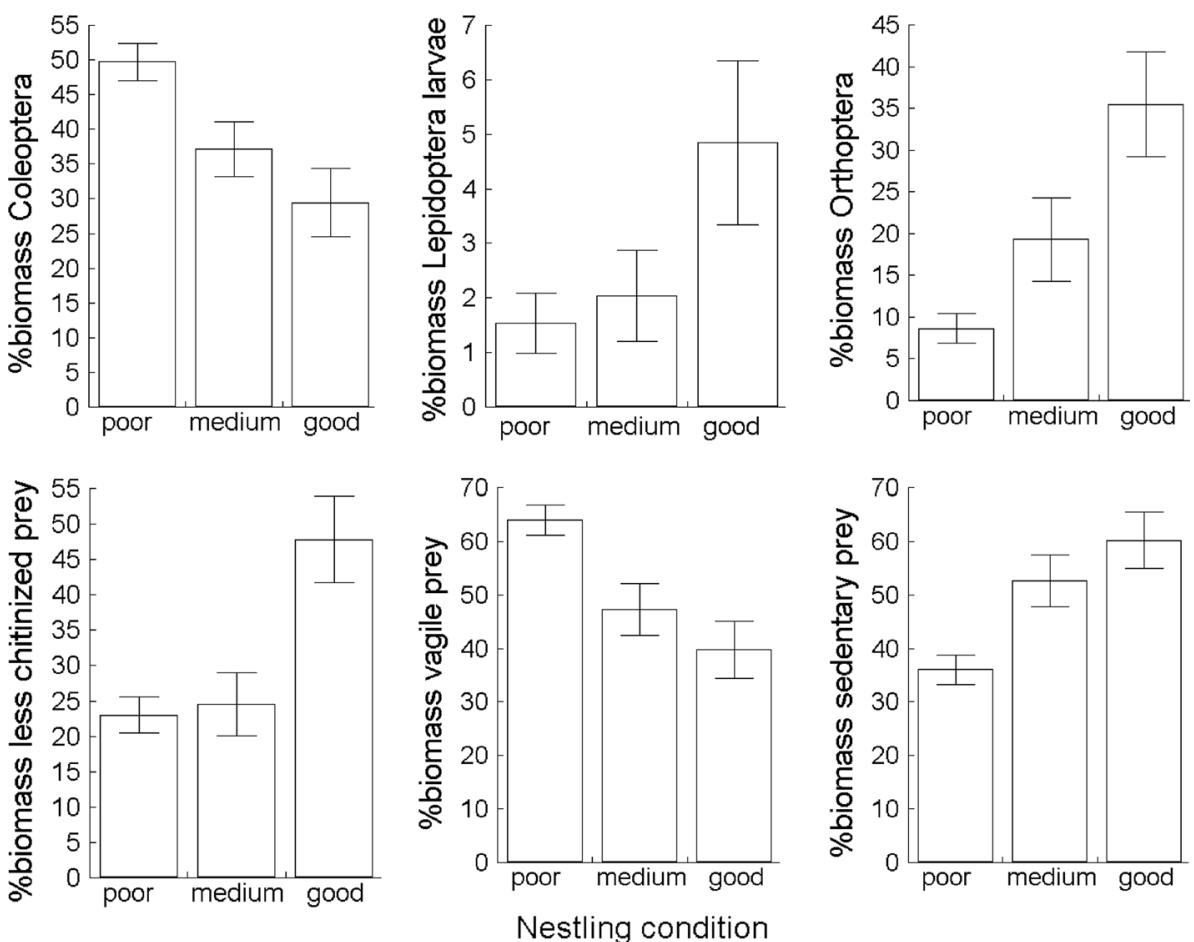

foraging sites are also possible. On the other hand, the analysis of the contribution of the functional prey groups seems more convincing, mostly because of the relatively smaller variation between the consecutive nestling age classes, compared to the more variable taxonomical division of prey.
We found evidence that nestling condition was positively correlated with the contribution of Lepidoptera larvae and Orthoptera or sedentary (mostly large-bodied) prey taxa, and negatively with the contribution of Coleoptera or vagile prey taxa in the diet, but not with the area of the patch where Whinchats bred. In this respect, in so far as 
several earlier studies had already discovered a positive relationship between the contribution of lepidopteran larvae (or insect larvae/soft-bodied prey) and nestling condition (Donald et al. 2001; Bańbura et al. 1999; García-Navas and Sanz 2011), we confirmed an analogous relationship for Orthoptera, i.e. the largest ingested prey items in our study. Owing to their high caloric value, Orthoptera are presumably as beneficial as lepidopteran larvae for nestling condition. A similar finding, namely, a positive relationship between nestling body mass and the availability of certain orthopterans occurring in larger rectangular patches of early successional stages of woodland, was reported by Weldon and Haddad (2005). In contrast, we observed a negative relationship between nestling condition and the contribution of highly chitinized Coleoptera. Overall, this could be due to the poorer digestibility and lower water content of these insects (Studier and Sevick 1992), which translate into a smaller energy gain compared to the ingestion of more energy-rich caterpillars and Orthoptera (Brodmann and Reyer 1999). Moreover, apart from the fact that Orthoptera and Lepidoptera larvae supply a lot of water and are easier to digest, they presumably contain a certain amount of indigestible plant remains for nestling Whinchats, which may appear to increase their body mass. On the other hand, our study did not confirm the relationship between nestling condition and breeding patch area. It may be that parent birds compensate for the negative impacts of a deteriorating environment (i.e. a smaller breeding patch area) by working harder to get the same or reduced amount of food for their young, thereby maintaining a standard reproductive output (Brickle et al. 2000; Morris et al. 2001; Britschgi et al. 2006); our previous investigation in this study area did not provide any evidence that the area of abandoned fields where the Whinchats bred affected their breeding success or productivity (Frankiewicz 2010).

We found evidence that Whinchat broods from larger patches of non-cropped vegetation received more sedentary and heavier prey such as Orthoptera, Araneae and soildwelling invertebrates (such as Diplopoda/Mollusca). These results seem to confirm our prediction that large patches of vegetation that are not cropped (i.e. larger abandoned fields) but are managed agriculturally are refuges for less vagile or more sedentary species of invertebrates, which (mostly due to the severe mortality caused by farm machinery) did not normally occur in cropped areas. In particular, this applies to Araneae and orthopterans, which are very vulnerable to machinery-induced mortality, and which thus occur in considerably higher abundance in transitional habitats with successional vegetation, like abandoned grasslands or crop fields, after the cessation of agricultural management (Siemann et al. 1999; Humbert et al. 2009; Marini et al. 2009), as well as in traditionally managed grasslands (Britschgi et al. 2006). Interestingly, earlier dietary studies of nestling Whinchats from different grassland habitats showed that orthopterans (Saltatoria) and Aranaea were rather less-preferred prey types and that the selectivity of these prey types was apparently lower or similar (Bastian and Bastian 1996; Britschgi et al. 2006) compared to their occurrence in the habitat. Britschgi et al. (2006) claimed that orthopterans were under-represented in the diet of nestling Whinchats primarily because of the high level of chitin they contain. However, it should be remembered that parent Whinchats [like other bird species preying on large orthopterans (Kaspari 1991; Bańbura et al. 1999)] most probably prepared these large insects before feeding them to their nestlings by removing highly chinitized body parts, such as legs (this seems particularly necessary in the largest taxa consumed, e.g. Metrioptera), since these insect parts were not recovered in the analysed faeces of nestling Whinchats. To date, in our sample the overall contribution (by number) of orthopterans in the diet of nestling Whinchats was $6.5 \%$ (Table S1), although it varied between different age classes and its maximum percentage contribution was nearly $20 \%$ (by number) or as much as $42 \%$ (by biomass) in 4-day-old nestlings (see Fig. 2). This corresponds to previous detailed dietary data reported, namely, a 3-12.8\% numerical share of orthopterans in the diet of Whinchat nestlings (Suter 1988; Kleinschmidt 2001). Another potential explanation for the lesser use of orthopteran prey by Whinchats in grasslands (Britschgi et al. 2006) may be the relatively longer handling and preparation time with this prey type compared to the easily swallowed caterpillars and spiders (Banbura et al. 1999). In addition, Aranaea are primarily fed to the youngest nestlings (Magrath et al. 2004; Ramsay and Houston 2003): such a pattern of provisioning nestlings with spiders (35\% of all prey by number in 3-day-old nestlings) was confirmed in our study. This implies that different developmental stages of nestlings should be considered in dietary/foraging studies in order to acquire the full picture of the dietary/food requirements of Whinchats and perhaps also other insectivorous passerine nestlings. Finally, it should borne in mind that Whinchats adapt rapidly to increased food density and that they are under strong selection for efficiency (Andersson 1981). Thus, the presence of some abundant invertebrate prey in our samples, such as orthopterans or large beetles like the Garden Chafer Phyllopertha horticola (nearly $24 \%$ of all prey identified; Table S1), presumably indicates that parent Whinchats make use of the largest invertebrate prey available near the perching site (Kleinschmidt 2001).

In turn, we found that nestling Whinchats from smaller patches received lighter prey, primarily the consequence of a lower proportion of large-bodied orthopterans, and that the contribution of Coleoptera, Heteroptera, 
Lepidoptera larvae, intermediately chitinized, crop-specific, non-crop-specific, vagile or prey from vegetation, as well as aerial insects, was greater in these patches. This might be indicative of an edge effect, due mostly to an increasing abundance of some edge invertebrate species and/or differences in the composition of the invertebrate community representing both the taxa living in noncropped vegetation and floaters from adjacent crops (such as some Coleoptera) (Siemann et al. 1999; Holland and Luff 2000; Tscharntke et al. 2005). Alternatively, there may be such a large amount of all these prey items near the nest that it is useful for the parents to exploit them. Loading time is thus shorter, and it makes sense to deliver smaller prey and raise the feeding frequency without having to expend more energy (Andersson 1981). Consequently, such changes in the invertebrate community might lead to a behavioural/dietary adjustment in the parent Whinchats, primarily in their hunting technique, i.e. more aerial hunts/insects, when other prey groups are scarce owing to the small patch area, as an alternative to foraging in adjacent crops. For example, it may be a very economical method to catch bigger flies when on a warm, sunny day with a light breeze these insects are driven in the direction of the perch (Bastian and Bastian 1996). Therefore, weather conditions and the exact time of day when the faecal sacs were collected would also have an important influence on the dietary composition in nestling Whinchats, especially in the context of the functional aspect of prey. Furthermore, differences in the collection timing of faecal sacs between different years may also have had an influence on the dietary composition: this generally seems to explain the observed significant differences in the contributions of the three prey groups (Aranaea, Lepidoptera larvae and Orthoptera) during the 4 years of the study.

On the other hand, the overall low percentage of cropspecific invertebrate prey in the nestling diet $(<10 \%$ of each analysed dietary characteristic across all analysed age classes; see Fig. 3) might confirm the strong preference of Whinchats for foraging within the occupied patches of abandoned cropland (Frankiewicz 2010). Further, our dietary analysis showed that for Whinchats soil-dwelling invertebrates tended to be of secondary importance as food because the majority of prey items ( $>70 \%$ in each age class) were those associated with vegetation. This seems to imply indirectly the importance of a mosaic-like structure of the microhabitat with low vegetation or vegetation-free patches and bare ground, where prey are more accessible and the hunting of foraging Whinchats is more efficient (Bastian et al. 1994; Bastian and Bastian 1996; Andersson et al. 2009). Lastly, we were able to identify some invertebrate prey items only to the level of class/order (such as Araneae or Lepidoptera larvae), which to some degree hampered a more detailed analysis and the drawing of further inferences.

One should bear in mind the fact that the structure and composition of vegetation, and thus indirectly also the availability of soil surface and the potential soil-dwelling invertebrate prey present there, vary between grasslands and abandoned fields: in the former the vegetation is more condensed and access to the soil surface is limited. Consequently, owing to the lack of the compact layer of vegetation normally occurring in grasslands, the soil on abandoned farmland was drier. Presumably this is beneficial for some soil-dwelling invertebrates, such as ants, some coleopterans and orthopterans (which are abundant in the diet of the nestling Whinchats we examined), which are also easier to catch on bare ground or in lower vegetation (Andersson et al. 2009; Schaub et al. 2010). In addition, it should be stressed that Whinchats hunt primarily from a perch, so both the denser vegetation (i.e. more concealed prey) and the perch height (or even the lack of perches in modern grasslands) are of critical importance for access to prey and hunting efficiency (Andersson 1981; Andersson et al. 2009). This concurs with the assumption that the mobility of ground-foraging insectivorous passerines and access to food are of greater importance during the selection of a foraging site than the abundance of food per se, which translates into preferential foraging in short vegetation, even though more invertebrate prey were available in tall vegetation (discussed in van Oosten et al. 2014; Schaub et al. 2010). Therefore, it is possible that the recent successful colonization of abandoned farmland by the Whinchat and its population increase in this new habitat are in part simply the consequence of favourable foraging conditions and the excellent accessibility of prey in the loose vegetation or bare ground present there.

Four major conclusions with some critical implications for future ecological/dietary studies of Whinchats and other grassland passerines can be drawn from our investigation.

We found that the diet of nestling Whinchats from larger patches contained basically more profitable (mostly heavier) prey. Evidence demonstrating that food limitation is a likely mechanism of area sensitivity in Whinchats breeding in patches of abandoned farmland therefore seems to be in part justified. However, this needs further detailed investigations analysing food supply/quality in patches of abandoned crop fields of different sizes and vegetation types.

The dietary composition and presumably the specific nutritional needs of nestlings in different age classes vary primarily with respect to the contribution of soft-bodied prey. Consequently, dietary records (and perhaps concurrent potential food resources) need to be sampled throughout the brood-rearing period. Dietary composition and the prey attributes of nestlings (between various 
populations/areas) should be compared only for similar age classes of offspring. Otherwise, sampling without reference to nestling age will not lead to correct inferences about relationships between food supply and environment.

Besides the previously reported additional factors affecting optimal diet and foraging strategy, which are a simultaneous resolution of various cost-benefit functions (sensu Brodmann and Reyer 1999), our results add to this dietary optimization (compensation strategy), as it is a trade-off between a brood's nutritional demands and patch size. This implies a continuum in dietary optimization in that the parent birds deliver the top-ranked invertebrates present mostly within a patch. In other words, this suggests that parent Whinchats can overcome habitat constraints resulting from the small area of a breeding patch by incorporating interchangeably the two major prey groups (Orthoptera and Lepidoptera) in the diet they feed to their nestlings. This is the ultimate justification for stating that their condition is independent of patch size. On the other hand, breeding on small patches may only be possible if there is a sufficiency of available prey items. Consequently, it is also possible that some prey groups will be more abundant in adjacent crops (such as lepidopteran larvae). Therefore the quality of small patches chosen for breeding could be similar or even higher (e.g. when agriculturally subsidized prey are numerous) than that of larger patches.

The prey taxa identified in the diet of the nestling Whinchats we studied are largely characteristic of dry habitats, compared to the rather moister condition of most semi-natural European grasslands. In sum, this implies that the quality rather than the quantity or accessibility of food per se is the key factor determining the breeding occurrence of Whinchats. Indirectly, given the colonization success and overall increase in populations of the Whinchat in abandoned farmland areas, this suggests that progressive climate change (mostly shortages of rainfall and reductions in temperature) are not disadvantageous for this species [e.g. in the Scottish Highlands Whinchats preferred warmer south-facing hillsides (Calladine and Bray 2012)]. One can assume that the major threats to Whinchats and other birds breeding in grasslands nowadays are the direct mortality/ nest losses of birds due to mowing and the intensification of agricultural management as a result of the encroachment of tall grass species resulting from nitrogen deposition and acidification, which diminish habitat suitability and reduce prey accessibility (Vickery et al. 2001; Broyer et al. 2014; Fischer et al. 2013; van Oosten et al. 2014).

Finally, we would like to highlight the need for further in situ studies aimed at identifying the link between the foraging success of Whinchats and other grassland birds and the vegetation structure in both grasslands and new substitute habitats, such as abandoned farmland. Given the considerable increase in such areas in certain parts of the world, such studies are imperative. They should analyse the dietary, behavioural and physiological responses and demography of birds towards size, habitat composition and landscape configuration of patches of non-cropped vegetation growing on fallow land.

Acknowledgments Peter Senn kindly corrected the English of the manuscript. All procedures regarding this study were conducted in compliance with Polish legislation. The permits for conducting the study were accepted by the II Ethics Commission in Wrocław. Licences for bird ringing were issued by the Ornithological Station of the Polish Academy of Sciences based on decisions of the Polish Ministry of Environment.

Open Access This article is distributed under the terms of the Creative Commons Attribution 4.0 International License (http://crea tivecommons.org/licenses/by/4.0/), which permits unrestricted use, distribution, and reproduction in any medium, provided you give appropriate credit to the original author(s) and the source, provide a link to the Creative Commons license, and indicate if changes were made.

\section{References}

Andersson M (1981) Central place foraging in whinchats, Saxicola rubetra. Ecology 62:538-544

Andersson M, Wallander J, Isaksson D (2009) Predator perches: a visual search perspective. Funct Ecol 23:373-379

Bańbura J, Lambrechts M, Blondel J, Perret P, Cartan-Son M (1999) Food handling time of blue tit chicks: constraints and adaptation to different prey types. J Avian Biol 30:263-270

Bastian H, Bastian A (1993) Entwicklung der Körpermasse nestjunger Braunkehlchen (Saxicola rubetra). J Ornithol 134:85-92

Bastian A, Bastian H (1996) Das Braunkehlchen. Opfer der ausgeräumten Kulturlandschaft. Aula, Wiesbaden

Bastian H, Feulner J (eds) (2015) Living on the edge of extinction in Europe. In: Proceedings of 1st European Whinchat Symposium., LBV Hof, Helmbrechts

Bastian A, Bastian H, Sternberg H (1994) Ist das Nahrungsangebot für die Brutrevierwahl von Braunkehlchen Saxicola rubetra entscheidend? Vogelwelt 115:103-114

Bayard TS, Elphick C (2010) How area sensitivity in birds is studied. Conserv Biol 24:938-947

Blackburn E, Cresswell W (2016) High within-winter and annual survival rates in a declining Afro-Palaearctic migratory bird suggest that wintering conditions do not limit populations. Ibis 158:92-105

Bortolotti GR, Tella J, Forero M, Dawson R, Negro J (2000) Genetics, local environment and health as factors influencing plasma carotenoids in wild American kestrels (Falco sparverius). Proc R Soc Lond B 267:1433-1438

Brickle NW, Harper D, Aebischer N, Cockayne S (2000) Effects of agricultural intensification on the breeding success of corn buntings Miliaria calandra. J Appl Ecol 37:742-755

Britschgi A, Spaar R, Arlettaz R (2006) Impact of grassland farming intensification on the breeding ecology of an indicator insectivorous passerine, the Whinchat Saxicola rubetra: lessons for overall Alpine meadowland management. Biol Conserv 130:193-205

Brodmann PA, Reyer H (1999) Nestling provisioning in water pipits (Anthus spinoletta): do parents go for specific nutrients or profitable prey? Oecologia 120:506-514 
Broyer J (2009) Whinchat Saxicola rubetra reproductive success according to hay cutting schedule and meadow passerine density in alluvial and upland meadows in France. J Nat Conserv $17: 160-167$

Broyer J, Curtet L, Boissenin M (2012) Does breeding success lead meadow passerines to select late mown fields? J Ornithol $153: 817-823$

Broyer J, Sukhanova O, Mischenko A (2014) Mowing management and density dependence in meadow passerine hatching success. Bird Study 61:394-403

Burke DM, Nol E (1998) Influence of food abundance, nest-site habitat, and forest fragmentation on breeding Ovenbirds. Auk 115:96-104

Calladine J, Bray J (2012) The importance of altitude and aspect for breeding Whinchats Saxicola rubetra in the uplands: limitations of the uplands as a refuge for a declining, formerly widespread species? Bird Study 59:43-51

Crossley DA Jr, Coleman D, Hendrix P (1989) The importance of the fauna in agricultural soils: research approaches and perspectives. Agric Ecosyst Environ 27:47-55

Donald PF, Muirhead L, Buckingham D, Evans A, Kirby W, Gruar D (2001) Body condition, growth rates and diet of Skylark Alauda arvensis nestlings on lowland farmland. Ibis 143:658-669

Fischer K, Busch R, Fahl G, Kunz M, Knopf M (2013) Habitat preferences and breeding success of Whinchats (Saxicola rubetra) in the Westerwald mountain range. J Ornithol 154:339-349

Flinks H, Pfeifer F (1988) Einfluß des Nestlingsalters auf die Nahrungszusammensetzung nestjunger Schwarzkehlchen (Saxicola torquata). J Ornithol 129:317-324

Frankiewicz J (2008) Breeding biology and ecology of Whinchat Saxicola rubetra on abandoned farmland of Opole Province (SW Poland). Acta Zool Cracoviensia 51A:35-47

Frankiewicz J (2010) Wpływ czynników środowiskowych i populacyjnych na sukces lęgowy pokląskwy Saxicola rubetra. $\mathrm{PhD}$ thesis. Department of Avian Ecology, University of Wrocław, Wrocław, Poland

Frankiewicz J (2015) The influence of environmental factors on breeding success of the Whinchat Saxicola rubetra. In: Bastian HV, Feulner J (eds): Living on the edge of extinction in Europe. Proceedings of 1st European Whinchat Symposium, LBV Hof, Helmbrechts, pp 165-166

García-Navas V, Sanz J (2011) The importance of a main dish: nestling diet and foraging behaviour in Mediterranean Blue Tits in relation to prey phenology. Oecologia 165:639-649

García-Navas V, Ferrer E, Sanz J (2012) Prey selectivity and parental feeding rates of Blue Tits Cyanistes caeruleus in relation to nestling age. Bird Study 59:236-242

Grüebler MU, Schuler H, Müller M, Spaar R, Horch P, Naef-Daenzer B (2008) Female biased mortality caused by anthropogenic nest loss contributes to population decline and adult sex ratio of a meadow bird. Biol Conserv 141:3040-3049

Grüebler MU, Schuler H, Horch P, Spaar R (2012) The effectiveness of conservation measures to enhance nest survival in a meadow bird suffering from anthropogenic nest loss. Biol Conserv 146:197-203

Guillod N, Arlettaz R, Jacot A (2016) Impact of spatial variation of a crucial prey, the Molecricket, on Hoopoe territory occupancy and reproduction. J Avian Biol. doi:10.1111/jav.00990

Henderson I, Calladine J, Massimino D, Taylor J, Gillings S (2014) Evidence for contrasting causes of population change in two closely related, sympatric breeding species the Whinchat Saxicola rubetra and Stonechat Saxicola torquata in Britain. Bird Study 61:553-565
Hinsley SA, Rothery P, Bellamy P (1999) Influence of woodland area on breeding success in Great Tits Parus major and blue tits Parus caeruleus. J Avian Biol 30:271-281

Holland JM, Luff M (2000) The effects of agricultural practices on Carabidae in temperate agroecosystems. Integr Pest Manage Rev 5:109-129

Humbert J, Ghazoul J, Walter T (2009) Meadow harvesting techniques and their impacts on field fauna. Agric Ecosyst Environ 130:1-8

Kamp J, Urazaliev R, Balmford A, Donald P, Green R, Lamb A, Phalan B (2015) Agricultural development and the conservation of avian biodiversity on the Eurasian steppes: a comparison of land-sparing and land-sharing approaches. J Appl Ecol 52:1578-1587

Karg J (1989) Differentiation in the density and biomass of flying insects in the agricultural landscape of Western Poland. Rocz Akad Roln Pozn 188:1-78 (in Polish)

Kaspari M (1991) Prey preparation as a way that Grasshopper Sparrows (Ammodramus savannarum) increase the nutrient concentration of their prey. Behav Ecol 2:234-241

Keyel AC, Bauer C, Lattin C, Romero L, Reed J (2012) Testing the role of patch openness as a causal mechanism for apparent area sensitivity in a grassland specialist. Oecologia 169:407-418

Kleinschmidt L (2001) Ekologia gniazdowania pokląskwy Saxicola rubetra $\mathrm{w}$ województwie warmińsko-mazurskim. PhD thesis, Uniwersytet Gdański, Gdańsk, Poland

Krebs JR, Davies N (1991) Behavioural ecology: an evolutionary approach, 3rd edn. Blackwell, Oxford

Le Tortorec E, Helle S, Käyhkö N, Suorsa P, Huhta E, Hakkarainen H (2013) Habitat fragmentation and reproductive success: a structural equation modelling approach. J Anim Ecol 82:1087-1097

Lourenço R, del Mar Delgado M, Campioni L, Korpimäki E, Penteriani V (2015) Evaluating the influence of diet-related variables on breeding performance and home range behaviour of a top predator. Popul Ecol 57:625-636

Magrath MJ, van Lieshout E, Visser G, Kondeur J (2004) Nutritional bias as a new mode of adjusting sex allocation. Proc R Soc Lond B (Suppl) 271:347-349

Marini L, Fontana P, Battisti A, Gaston K (2009) Response of orthopteran diversity to abandonment of semi-natural meadows. Agric Ecosyst Environ 132:232-236

Martin TE (1987) Food as a limit on breeding birds: a life-history perspective. Annu Rev Ecol Syst 18:453-487

Matuszkiewicz W (2005) Przewodnik do oznaczania zbiorowisk roślinnych Polski. PWN Warszawa, Poland

Mitrus C, Mitrus J, Sikora M (2010) Changes in nestling diet composition of the red-breasted flycatcher Ficedula parva in relation to chick age and parental sex. Anim Biol 60:319-328

Møller AP, Rubolini D, Lehikoinen A (2008) Populations of migratory bird species that did not show a phenological response to climate change are declining. Proc Nat Acad Sci USA 105(16): 195-200

Morris AJ, Whittingham M, Bradbury R, Wilson J, Kyrkos A, Buckingham D, Evans A (2001) Foraging habitat selection by yellowhammers (Emberiza citrinella) nesting in agriculturally contrasting regions in lowland England. Biol Conserv 101:197-210

Müller M, Spaar R, Schifferli L, Jenni L (2005) Effects of changes in farming of subalpine meadows on a grassland bird, the Whinchat (Saxicola rubetra). J Ornithol 146:14-23

Murphy MT, Moore F (2003) Avian population trends within the evolving agricultural landscape of eastern and central United States. Auk 120:20-34 
Oppermann R (1999) Nahrungsökologische Grundland und Habitatansprüche des Braunkehlchens Saxicola rubetra. Vogelwelt 120:7-25

Orłowski G (2004) Abandoned cropland as a habitat of the Whinchat Saxicola rubetra in SW Poland. Acta Ornithol 39:60-66

Orłowski G (2005) Endangered and declining bird species of abandoned farmland in south-western Poland. Agric Ecosyst Environ 111:231-236

Orłowski G, Karg J (2011) Diet of nestling Barn Swallows Hirundo rustica in rural areas of Poland. Centr Eur J Biol 6:1023-1035

Orłowski G, Karg J (2013) Diet breadth and overlap in three sympatric aerial insectivorous birds at the same location. Bird Study 60:475-483

Orłowski G, Rusiecki S, Karg J (2014a) Partial dietary segregation between adult and nestling Bluethroats Luscinia svecica. Acta Ornithol 49:107-118

Orłowski G, Karg J, Karg G (2014b) Functional invertebrate prey groups reflect dietary responses to phenology and farming activity and pest control services in three sympatric species of aerially foraging insectivorous birds. PLoS One 9:e114906. doi:10.1371/journal.pone.0114906

Orłowski G, Wuczyński A, Karg J (2015) Effect of brood age on nestling diet and prey composition in a hedgerow specialist bird, the barred warbler Sylvia nisoria. PLoS One 10(6):e0131100. doi:10.1371/journal.pone.0131100

Perlut NG, Strong A, Donovan T, Buckley N (2008) Grassland songbird survival and recruitment in agricultural landscapes: implications for source-sink demography. Ecology 89:1941-1952

Plieninger T, Hui C, Gaertner M, Huntsinger L (2014) The impact of land abandonment on species richness and abundance in the Mediterranean basin: a meta-analysis. PLoS One 9:e98355. doi:10.1371/journal.pone.0098355

Pudil M, Exnerová A (2015) Diet and foraging behaviour of the Whinchat (Saxicola rubetra). In: Bastian HV, Feulner J (eds) Living on the edge of extinction in Europe. Proceedings of the 1st European Whinchat Symposium, LBV Hof, Helmbrechts, pp 125-134

Quan R, Li H, Wang B, Goodale E (2015) The relationship between defecation and feeding in nestling birds: observational and experimental evidence. Front Zool 12:21. doi:10.1186/s12983015-0116-y

Radford AN (2008) Age-related changes in nestling diet of the cooperatively breeding Green Woodhoopoe. Ethology 114:907-915

Ramsay SL, Houston D (2003) Amino acid composition of some woodland arthropods and its implications for breeding tits and other passerines. Ibis 145:227-232

Ribic CA, Koford R, Herkert J, Johnson D, Niemuth N, Naugle D, Bakker K, Sample D, Renfrew R (2009) Area sensitivity in North American grassland birds: patterns and processes. Auk 126:233-244

Sanderson FJ, Donald P, Pain D, Burfield I, van Bommel F (2006) Long-term population declines in Afro-Palearctic migrant birds. Biol Conserv 131:93-105

Sanderson FJ, Kucharz M, Jobda M, Donald P (2013) Impacts of agricultural intensification and abandonment on farmland birds in Poland following EU accession. Agric Ecosyst Environ 168:16-24
Schaub M, Martinez N, Tagmann-Ioset A, Weisshaupt N, Maurer ML, Reichlin T, Abadi F, Zbinden N, Jenni L, Arlettaz R (2010) Patches of bare ground as a staple commodity for declining ground foraging insectivorous farmland birds. PLoS One 5:e13115. doi:10.1371/journal.pone.0013115

Shitikov DA, Vaytina T, Gagieva V, Fedchuk D (2015) Breeding success affects site fidelity in a Whinchat Saxicola rubetra population in abandoned fields. Bird Study 62:96-105

Siemann E, Haarstad J, Tilman D (1999) Dynamics of plant and arthropod diversity during old field succession. Ecography 22:406-414

Strebel G, Jacot A, Horch P, Spaar R (2015) Effects of grassland intensification on Whinchats Saxicola rubetra and implications for conservation in upland habitats. Ibis 157:250-259

Studier EH, Sevick S (1992) Live mass, water content, nitrogen and mineral levels in some insects from south-central Lower Michigan. Comp Biochem Physiol 103A:579-595

Suorsa P, Huhta E, Nikula A, Nikinmaa M, Jäntti A, Helle H, Hakkarainen H (2003) Forest management is associated with physiological stress in an old-growth forest passerine. Proc $\mathrm{R}$ Soc Lond B 270:963-969

Suter W (1988) Saxicola rubetra (Linnaeus 1758)—Braunkehlchen. In: Glutz von Blotzheim UN (ed) Handbuch der Vögel Mitteleuropas. AULA, Wiesbaden, pp 392-446

Tryjanowski P, Kuźniak S, Kujawa K, Jerzak L (2009) Ekologia ptaków krajobrazu rolniczego. Bogucki Wyd Nauk, Poznan

Tscharntke T, Rand T, Bianchi F (2005) The landscape context of trophic interactions: insect spillover across the crop-non-crop interface. Ann Zool Fenn 42:421-432

van Oosten H, van den Burg A, Versluijs R, Siepel H (2014) Habitat selection of brood-rearing Northern Wheatears Oenanthe oenanthe and their invertebrate prey. Ardea 102:61-69

Vickery PD, Herkert J (2001) Recent advances in grassland bird research: where do we go from here? Auk 118:11-15

Vickery JA, Tallowin J, Feber R, Asteraki E, Atkinson P, Fuller R, Brown V (2001) The management of lowland neutral grasslands in Britain: effects of agricultural practices on birds and their food resources. J Appl Ecol 38:647-664

Weldon AJ, Haddad NM (2005) The effects of patch shape on Indigo Buntings: evidence for an ecological trap. Ecology 86:1422-1431

Wiens J, Rotenberry J (1979) Diet niche relationships among North American grassland and shrubsteppe birds. Oecologia 42:253-292

Wilkin TA, King LE, Sheldon BC (2009) Habitat quality, nestling diet, and provisioning behaviour in Great Tits Parus major. J Avian Biol 40:135-145

Wilson LJ, Daunt F, Wanless S (2004) Self-feeding and chick provisioning diet differ in the Common Guillemot Uria aalge. Ardea 92:197-208

Zakkak S, Radovic A, Nikolov S, Shumka S, Kakalis L, Kati V (2015) Assessing the effect of agricultural land abandonment on bird communities in southern-eastern Europe. J Environ Manage 164:171-179

Zanette L, Doyle P, Trémont S (2000) Food shortage in small fragments: evidence from an area-sensitive passerine. Ecology $81: 1654-1666$ 